\title{
THE EVALUATION OF DIFFERENT SORBENTS AND SOLVENT MIXTURES IN PAH SAMPLE PREPARATION FOR GC/GC-MS ANALYSIS
}

Jelena S. Cvetković*, Violeta D. Mitić, Vesna P. Stankov Jovanović, Marija V. Dimitrijević, Gordana S. Stojanović

University of Niš, Faculty of Sciences and Mathematics, Department of Chemistry, Niš, Serbia
(ORIGINAL SCIENTIFIC PAPER) UDC 543.51:547.6:66.061.3
GC/GC-MS-analysis of polycyclic aromatic hydrocarbons (PAHs) in complex samples requires a previous treatment of the samples. In order to establish the effects of sorbents/solvents on the overall accuracy of the method, dispersive solid phase extraction as a method for the sample preparation in PAHs determination is employed using three different solvent mixtures and sorbents (PSA, C18 and PS-DVB). Recovery values are dependent on compound and sorbents. The highest mean recovery was recorded for cyclohexane/acetone-C18 combination (58.45\%) which is satisfactory, with the values above $70 \%$ for naphthalene $(76.05 \%)$, fluoranthene $(80.22 \%)$, pyrene $(111.99 \%)$ and benzo[g,h,i]perylene $(71.77 \%)$. Similar recoveries were obtained for cyclohexane/acetone-PS-DVB (55.50\%) and cyclohexane/acetone-PSA (55.30\%). Cyclohexane/acetone gave the highest recovery values for all three sorbents, so this solvent mixture could be used in PAH extraction from various matrices. Though the obtained recovery values for the investigated sorbent/solvent combinations were not impressive, they might be a good basis for future researches since, as far as we know, PS-DVB was not used in dSPE sample preparation for GC/GC-MS analysis of PAHs.
Keywords: PAH, GC/GC-MS, sample preparation, dSPE, sorbent

\section{Introduction}

Polycyclic aromatic hydrocarbons (PAH) are ubiquitous environmental contaminants. PAHs are weakly dissolved in water and their solubility decreases with the increase of the number of aromatic rings. They can be divided to light and heavy PAHs. Light PAHs are those which have up to 4 fused benzene rings, while heavy PAHs are those with more than 4 fused benzene rings. Heavy PAHs persist in the environment because of the low volatility, resistance to leaching and recalcitrant nature. [1] International Agency for Research on Cancer (IARC) have classified PAHs as carcinogenic. [2] European Commission (EC) has placed $16 \mathrm{PAH}$ compounds (Table 1) on the pollutants priority list because of the potential toxicity and the frequency of occurrence. [3]

Sources of PAH can be natural (forest fires, volcanoes, plants, fungi and bacteria) and anthropogenic (electric power generation, petroleum industry/distribution, home heating, internal combustion engines/traffic and the production of coke). The contamination of the environment is mainly caused by anthropogenic processes. Polycyclic aromatic hydrocarbons are widespread and can be found in soil, air, water, and also in food and human tissues. [4,5] They are present in the environment due to incomplete combustion of organic matter. Emissions from traffic have been found to be the main outdoor source for the indoor
PAH concentration at urban and suburban locations in many industrialized countries [6], while indoor air is mainly polluted from tobacco smoke [7]. PAHs reach soil and water from the atmospheric deposition, through the discharge of industrial and domestic sewage effluents and spillages of petroleum products. [8] PAH contamination is of great concern since they have toxic, carcinogenic, teratogenic and mutagenic effects. [9]

Because of their prevalence in the environment, food and other life segments and evidenced harmful effects, $\mathrm{PAHs}$ analysis is of great significance. However, the measurement of the PAH concentration requires complicated, time consuming and tedious analytical procedures, as a result of the sample complexity. The analysis may be comprised during several steps: sampling, $\mathrm{PAH}$ extraction, the cleanup process and instrumental analysis. Extraction methods explored over the years include: Soxhlet's, ultrasonic, liquid-liquid, purge and trap, headspace, shaking, vortex, solid-phase, supercritical fluid extraction, solid-phase micro extraction (SPME), stir-bar sorptive extraction (SBSE), miniaturized solid-phase extraction (MSPE), liquid-phase micro extraction (LPME) and membrane-assisted solvent extraction techniques (MASE). [10] Clean-up methods for PAHs analysis include solvent partitioning and chromatographic proce-

\footnotetext{
*Author address: Jelena Cvetković, Faculty of Science and Mathematics, Department of Chemistry, University of Niš, Višegradska 33, 18000 Niš, Serbia

E-mail: jelena.cvetkovic7@gmail.com

The manuscript received: February, 24, 2016.

Paper accepted: March, 24, 2016.
} 
dures (column chromatography and thin layer chromatography). Adsorbents in use include silica, alumina (classical), florisil, BioBeads S-X3, polydimethylsiloxane, PDMS-divinylbenzene (PDMS-DVB), PDMS-Carbowax. [11] Identification and quantification methods the most frequently applied are Gas Chromatography, Gas Chromatography-Mass Spectrometry (GC-MS) and High Performance Liquid Chromatography (HPLC). In 2003, Anastassiades et al. [12] proposed a dispersive solid phase extraction technique (dSPE) which consists of organic solvent extraction followed by liquid-liquid partition with the addition of salt to effectsalting out and drying, and finally a clean-up step by solid sorbent extraction. This procedure offers much simpler, faster and cheaper sample preparation than other techniques used and the proposed acronym QuEChERS (Quick, Effective, Cheap,
Economic, Rugged, Safe) fully describes the main characteristics of the innovative method.

The aim of this study was to evaluate different sorbents and solvents for the sample cleanup in PAH analysis. The cleanup step is essential prior to chromatographic analysis, so the appropriate sorbent should be chosen to obtain a lower matrix effect and the best accuracy. In this experiment we assessed the convenience of three different sorbents usually used in SPE: primary secondary amine (PSA), octadecyl silica (C18) and styrenedivinylbenzene (PS-DVB) using three solvent mixtures (acetonitrile/methanol, hexane/acetone and cyclohexane/acetone). The effectiveness of each sorbent and the solvent mixture was verified based on the recovery ratio for each $\mathrm{PAH}$ compound.

Table 1. EC 16 priority pollutant PAHs and selected properties

\begin{tabular}{|c|c|c|c|c|}
\hline PAH name & Structure & $\begin{array}{c}\text { Molecular } \\
\text { formula }\end{array}$ & $\begin{array}{c}\text { CAS } \\
\text { number }\end{array}$ & $\begin{array}{c}\text { Molecular } \\
\text { weight (g mol } \\
1 \text { ) }\end{array}$ \\
\hline Naphthalene & & $\mathrm{C}_{10} \mathrm{H}_{8}$ & $91-20-3$ & 128 \\
\hline Acenaphthylene & & $\mathrm{C}_{12} \mathrm{H}_{8}$ & $208-96-8$ & 152 \\
\hline Acenaphthene & & $\mathrm{C}_{12} \mathrm{H}_{10}$ & $83-82-9$ & 154 \\
\hline Fluorene & & $\mathrm{C}_{13} \mathrm{H}_{10}$ & $86-73-7$ & 166 \\
\hline Phenanthrene & & $\mathrm{C}_{14} \mathrm{H}_{10}$ & $85-01-8$ & 178 \\
\hline Anthracene & & $\mathrm{C}_{14} \mathrm{H}_{10}$ & $120-12-7$ & 178 \\
\hline Fluoranthene & & $\mathrm{C}_{16} \mathrm{H}_{10}$ & $206-44-00$ & 202 \\
\hline Pyrene & & $\mathrm{C}_{16} \mathrm{H}_{10}$ & $129-00-0$ & 202 \\
\hline Benzo[a]anthracene & & $\mathrm{C}_{18} \mathrm{H}_{12}$ & $56-55-3$ & 228 \\
\hline
\end{tabular}




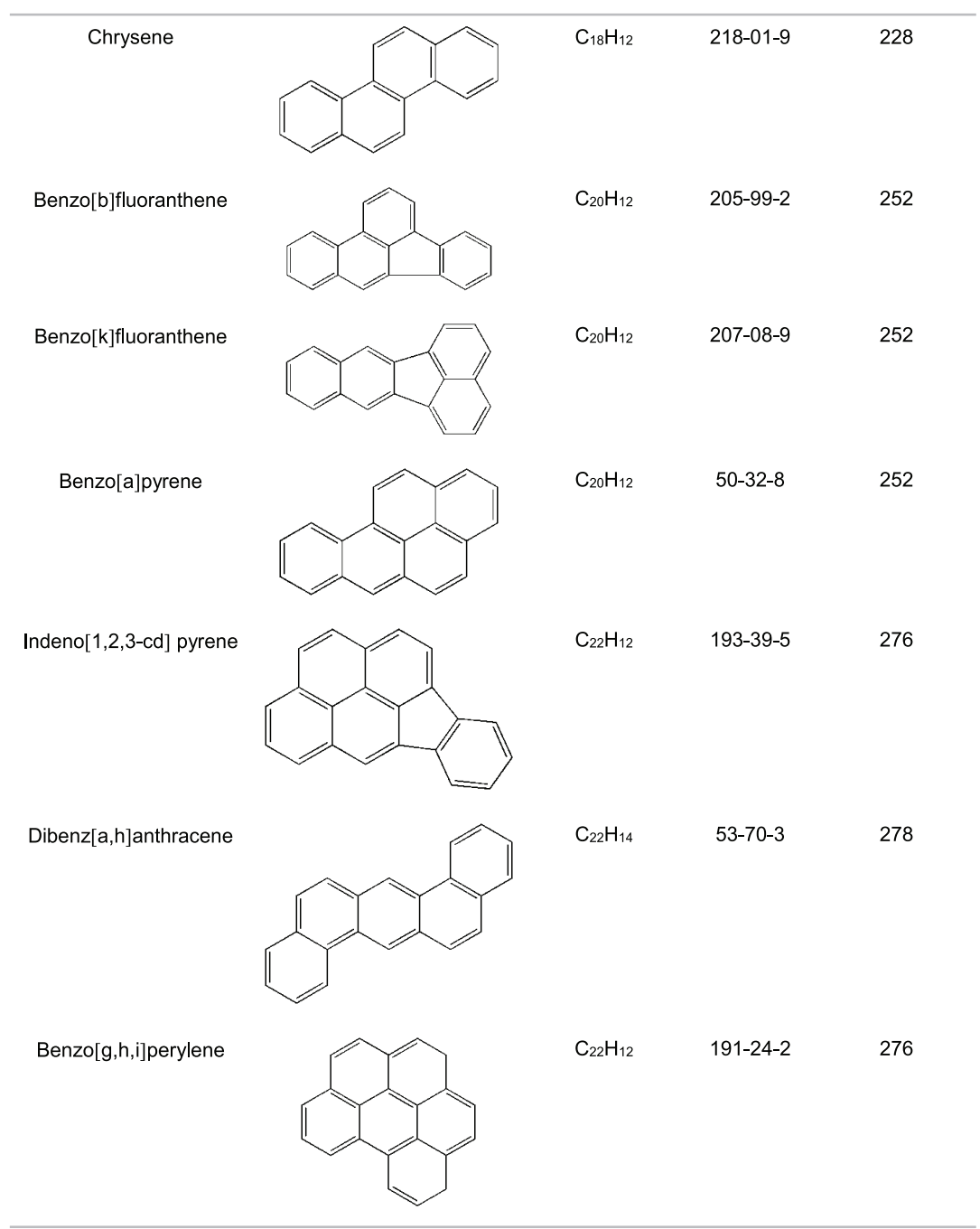

\section{Methods and materials}

\section{Chemical and reagents}

Acetonitrile (MeCN), hexane, cyclohexane, methanol HPLC - grade and MgSO4 were purchased from Sigma Aldrich. PAH Kit 601 - N containing acenaphthylene, anthracene, benzo[a]anthracene, benzo[a]pyrene, benzo[b] fluoranthene, benzo[g,h,i]perylene, benzo[k]fluoranthene, chrysene, dibenzo[a,h]anthracene, fluoranthene, fluorene, napthalene, phenanthrene, pyrene and internal standards (chrysene d10 and acenaphthene d10) derived from Supelco, Bellefonte, Pennsylvania. Working standard solution at the concentration $17.95 \mu \mathrm{g} / \mathrm{ml}$ for each PAH was prepared in different solvent mixtures: hexane/acetone $(1: 1, \mathrm{v} / \mathrm{v})$, cyclohexane/acetone $(1: 1$, $\mathrm{v} / \mathrm{v})$ and acetonitrile/methanol (2:1, v/v). PSA (primary secondary amine), C18 and styrene-divinylbenzene were purchased from Selectra UCT Bulk Sorbents.

Instrumentation

All extracts were analyzed on a 7890/7000B GCQqQ-MS system (Agilent Technologies, USA) in the selected ion monitoring (SIM) mode. The injector was PAL sampler, with the injection volume of $2.5 \mu \mathrm{l}$ in the splitless mode. Chromatographic separations were con- ducted using a HP-5MS (5\% Phenyl Methyl Siloxane) column $(30 \mathrm{~m} \times 250 \mu \mathrm{m} \times 0.25 \mu \mathrm{m})$. The GC oven was operated with the following temperature program: $75^{\circ} \mathrm{C}$ for 3 minutes then $6{ }^{\circ} \mathrm{C} /$ minute to $300{ }^{\circ} \mathrm{C}$ and kept for 10 minutes at this temperature. The total run time was 50.5 minutes. The analyses were conducted in the SIM mode based on the use of one quantitative ion. The analyzed compounds were identified according to their qualitative ions and retention times (Table 2).

\section{Sample preparation}

One milliliter of the standard solution was transferred into dSPE tube containing $50 \mathrm{mg}$ of the sorbent. The mixture was shaken for 1 minute and centrifuged at 8000 rpm for 10 minutes. The volume of $0.6 \mathrm{ml}$ of supernatant was transferred into $\mathrm{GC}$ vial, and $0.2 \mathrm{ml}$ of internal standard was added. The prepared solution was then analyzed by GC-MS. Reagent blank was prepared by adding clean solvents into the dSPE tube. A series of standard solutions in hexane were prepared by dilution of the standard solution in the range: $0.38,1.92,3.85$, $9.62,19.23,24.04,28.85$ and $38.46 \mu \mathrm{g} / \mathrm{ml}$. 
Table 2. Identification and quantification parameters of the analyzed compounds

\begin{tabular}{|c|c|c|c|c|}
\hline PAH name & $\begin{array}{c}\text { Rt } \\
\text { (minute) }\end{array}$ & Quantification ion & Calibration slope & Correlation coefficient \\
\hline Naphthalene & 12.087 & 128.0 & 2.428 & 0.98 \\
\hline Acenaphthene & 18.759 & 152.0 & 1.612 & 0.99 \\
\hline Fluorene & 20.688 & 165.0 & 1.841 & 0.99 \\
\hline Phenanthrene & 24.302 & 178.0 & 1.427 & 0.99 \\
\hline Anthracene & 24.478 & 178.0 & 0.869 & 0.99 \\
\hline Fluoranthene & 28.878 & 202.0 & 0.715 & 0.97 \\
\hline Pyrene & 29.696 & 202.0 & 6.389 & 0.95 \\
\hline Benzo[a]anthracene & 34.513 & 228.0 & 3.912 & 0.99 \\
\hline Chrysene & 34.360 & 228.0 & 2.572 & 0.99 \\
\hline Benzo[b]fluoranthene & 38.258 & 252.0 & 1.437 & 0.99 \\
\hline Benzo[k]fluoranthene & 38.347 & 252.0 & 1.658 & 0.99 \\
\hline Benzo[a]pyrene & 32.289 & 252.0 & 1.087 & 0.95 \\
\hline Dibenz[a,h]anthracene & 43.161 & 278.0 & 0.466 & 0.92 \\
\hline Benzo[g,h,i]perylene & 43.964 & 276.0 & 0.536 & 0.91 \\
\hline
\end{tabular}

\section{Results and discussion}

The selection of the appropriate sorbent for dSPE is one of the most important issues because it should give a clean extract for the chromatographic analysis and provide the highest recoveries of the analyzed compounds. Most of the used sorbents work on adsorption principle, thus some errors can be expected due to strong analytesorbent surface binding.
Recovery studies were conducted after adding PAH standard mixture to dSPE tube with different sorbents and applying various extraction solvent mixtures. The recovery was calculated by comparing the observed concentrations with the expected concentrations. The recoveries within 50-120\% [13] (according to Regulation 836/2011) were obtained in most cases for all 14 compounds. The results for all sorbent/solvent mixture combinations were given in Figures 1, 2 and 3.

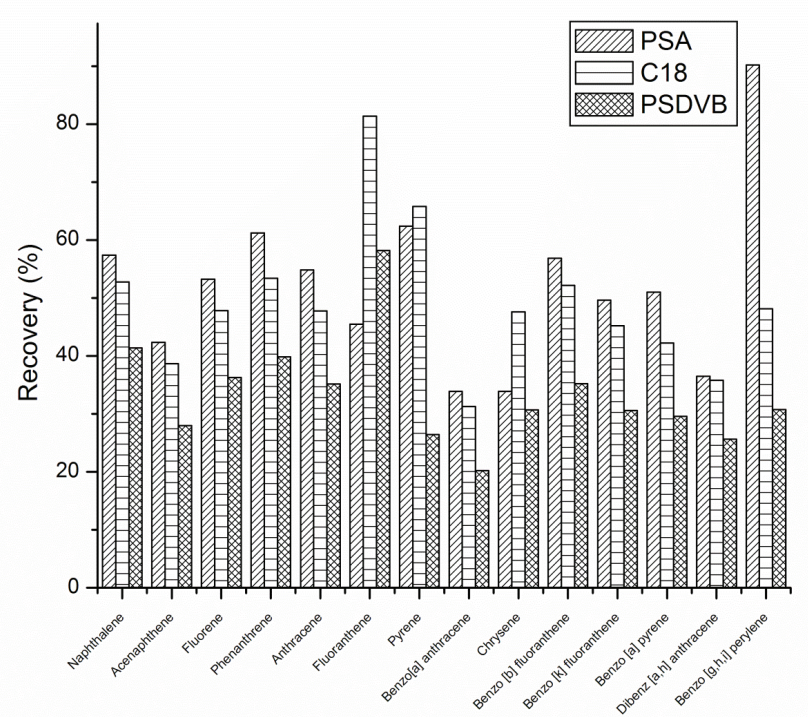

Figure 1. PAH recoveries using PSA, C18 and PS DVB as sorbents and hexane/acetone solvent mixture 


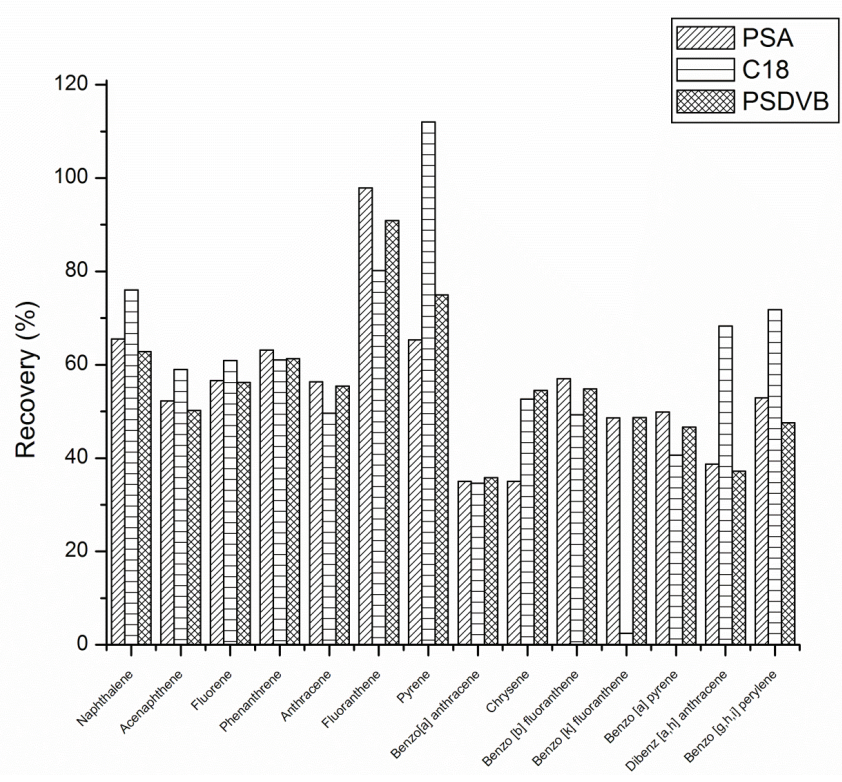

Figure 2. PAH recoveries using PSA, C18 and PS DVB as sorbents and cyclohexane/acetone solvent mixture

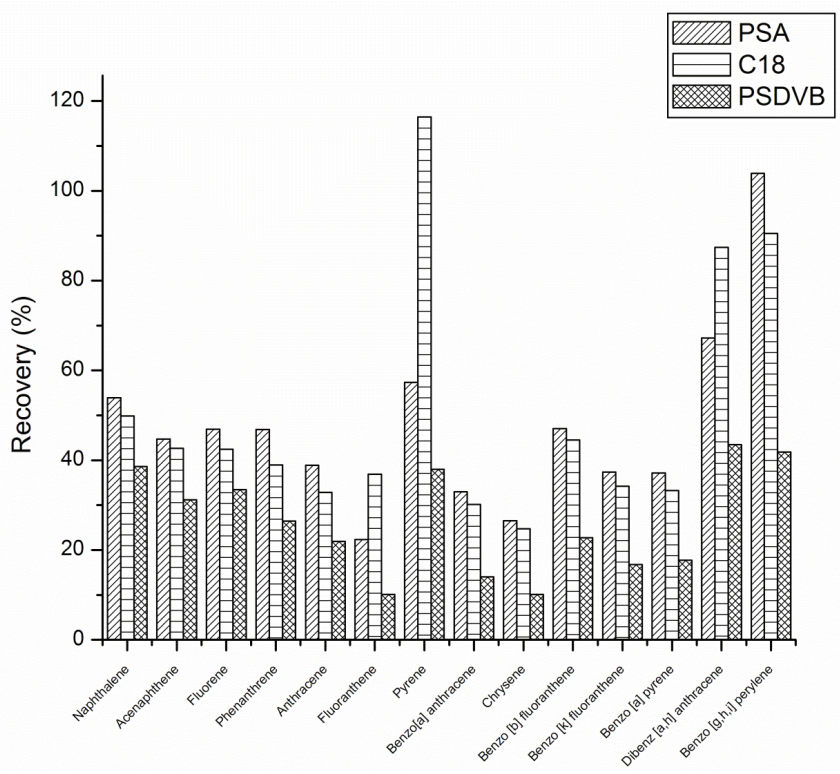

Figure 3. PAH recoveries using PSA, C18 and PS DVB as sorbents and acetonitrile/methanol solvent mixture

The most common SPE sorbent is PSA. It is silicabased material chemically bonded to ethyldiamine- $\mathrm{N}$ propyl group; PSA is a weak anion exchanger used for the extraction of anions exhibited at pH 8 or lower. Recovery values of PAHs using PSA and hexane/acetone mixture varied between $33.87 \%$ for benzo[a]anthracene and chrysene to $90.17 \%$ for benzo[g,h,i]perylene (Figure 1). Acceptable recovery values [13] using this sorbent/solvent mixture were also recorded for naphthalene, fluorene, phenanthrene, anthracene, pyrene, benzo[b] fluoranthene and benzo[a]pyrene. The mean recovery value using PSA-hexane/acetone combination was
$52.05 \%$. Cyclohexane/acetone and acetonitrile/methanol mixtures were also combined with PSA as a sorbent. Cyclohexane is a non-polar solvent, slightly more polar than hexane, the one of the solvents already used in PAH extraction, especially in polluted samples.[14] The combination of PSA and cyclohexane/acetone gave mean recovery of $55.30 \%$, with maximum recovery for fluoranthene $(98.89 \%)$, as shown in Figure 2. Acetonitrile was the first solvent used in QuECHERS pesticide analysis, but it is also used in PAH extraction.[15] Recovery values obtained by using the acetonitrile/methanol solvent mixture varied between $22.36 \%$ and $103.56 \%$, with the 
mean recovery value lower than the same for the other two combinations used (47.35\%). Maximum recovery using this solvent mixture was obtained for benzo[g,h,i] perylene (103.86\%) (Figure 3). Only pyrene, debenz[a,h] anthracene and benzo[g,h,i]perylene gave the recovery values higher than $50 \%$ (57.34\%, $67.24 \%$ and $103.86 \%$, respectively), which is not satisfactory, suggesting avoiding the PSA-acetonitrile/methanol combination in PAH analysis. The results obtained from the experiments used in this work (with three different solvent-mixtures combined with PSA sorbent) proved benzo[g.h,i]perylene as a $\mathrm{PAH}$-compound with the highest recovery value. Benzo[g.h,i]perylene is six-ring polycyclic aromatic hydrocarbon with the weaker binding ability to PSA. The idea of using a specific sorbent is to retain matrix components, but not the analytes of interest, so this sorbent can be used in the sample cleanup for benzo[g.h,i] perylene analysis. However, it can be seen that some of PAHs retain on the sorbent surface. Lower recovery values may be explained with the fact that acetone may react with PSA. PSA is a commonly used sorbent in dSPE technique which removes compounds like sugars, lipids, sterols and proteins. [12] Sadowska-Rociek et al. [15] suggested a modified QuEChERS technique, using different sorbents mixtures including PSA to obtain higher recoveries. Our preliminary experiments showed that some of analyzed PAHs remained on PSA surface, so sorbents mixtures and different solvents should be used to obtain higher recoveries, as suggested by SadowskaRociek et al. [15].

One of the most used SPE sorbents is C18 (octadecyl silica). Octadecyl bonded silica was first introduced in 1960s by Abel et al. [16]. Interactions of analytes with C-18/solvent combinations (retained/adsorbed analytes) could be the results of hydrogen bonding, van der Waals forces, and the polar character of the remained free silanol groups in the C-18 sorbent. Recovery values for analyzed PAH compounds for this sorbent and hexane/ acetone mixture varied between $31.26 \%$ for benzo[a]anthracene, to $81.36 \%$ for fluoranthene (Figure 1). Most of the analyzed compounds gave recoveries between 30 and $50 \%$, which can be explained by the nonpolar properties of this sorbent. Only five compounds gave recovery values higher than $50 \%$, which is lower than the values acceptable by Regulation 836/2011. [13] The best recoveries (within 50-120\%, according to Regulation 836/2011) [13] for almost all compounds were provided by the combinations of $\mathrm{C} 18$ sorbent together with the cyclohexane/acetone mixture. Mean recovery for this combination was $58.45 \%$, which is the highest value, compared to other analyzed C-18/solvent combinations. Only for benzo[a]anthracene, benzo[k]fluoranthene and benzo[a]pyrene satisfactory recoveries were not obtained (Figure 2). Higher recovery values were obtained for low molecular $\mathrm{PAH}$, which indicates greater binding affinity of higher PAHs to sorbent surface.

The combination of sorbent C18 with acetonitrile/ methanol gave the recovery values in the range of
$24.71 \%$ for chrysene to $116.42 \%$ for pyrene (Figure 3 ). In case of cyclohexane/acetone mixture, the highest recovery is obtained for pyrene by using C18 (Figure 2). Pyrene has been already used as a model compound to study biodegradation of heavy PAHs since it is structurally similar to several carcinogenic PAHs [17], and its analysis is of great importance. Octadecyl bonded silica could be used in the sample cleanup in pyrene analysis, since the highest recovery for this compound is obtained by using $\mathrm{C} 18$ as a sorbent. Another compound with high recovery using $\mathrm{C} 18$ is fluoranthene, $81.36 \%$ and $80.22 \%$ using hexane/acetone and cyclohexane/acetone mixture, respectively. Surma et al. [18] investigated the recoveries of $\mathrm{PAH}$ in various QuEChERS extraction modification, using $\mathrm{C} 18$ and PSA, as cleanup sorbents. The recoveries for PSA and C18 mixture varied between $72.4-110.8 \%$ [18]. The capacity of the sorbent is related to variations in chemical and physical parameters of bonded C18 that exists among different brands.

PS-DVB copolymer is a hydrophobic resin which has great analyte retention, mainly for polar compounds. [19] The recovery value from PS-DVB was lowest for benzo[a]anthracene $(20.20 \%)$ and highest for fluoranthene $(58.16 \%)$, using hexane/acetone solvent mixture (Figure 1). The recovery was higher for lower PAHs, compared to those with higher molar mass, probably due to stronger $\pi-\pi$ interactions between compounds with a higher molar mass. PS-DVB has higher potential over C18 for trapping thearomatic compound, especially phenols. [20] The use of polystyrene-divinylbenzene (PS-DVB) has been used for purification of PAHs in sediment. [21] However, in this manuscript, PS-DVB has been used in SPE cartridges which include analyte elution step. There is no elution step in dSPE technique, so analytes could remain on sorbent depending on both sorbent and analyte properties. The highest mean recovery was obtained using PS-DVB and cyclohexane/acetone mixture (55.50\%). Almost all analyzed compounds gave recovery acceptable values (Regulation 836/2011) [13]. Slightly higher recovery values were obtained for low molecular weight PAHs. The highest recovery was obtained for fluoranthene $(90.89 \%)$, which is also the case with the recovery using this sorbent and hexane/ acetone mixture where fluoranthene gave the recovery of $58.16 \%$ (Figures 1 and 2, respectively). The lowest mean recovery was obtained for PS-DVB as sorbent, using acetonitrile/methanol mixture (26.16\%). The highest recovery for this combination is obtained for dibenz[a,h] anthracene $(43.49 \%)$ as shown in Figure 3 , which is not above the recommended limit of $50 \%$, qualifying this sorbent/solvent combination as not suitable for the cleanup step in dSPE technique because of low recoveries for analyzed PAHs.

\section{Conclusion}

New sorbents and solvent mixtures were tested as alternatives to PSA in dSPE sample preparation technique 
in PAH analysis. Original dSPE procedure employs acetonitrile/methanol as solvents and PSA as a sorbent. Comparing mean recovery values of 14 analyzed compounds for PSA and the other two sorbents used in this assay, C18 and PS-DVB could also be used in dSPE with minor modifications in order to improve PAH recoveries. Priority should be given to $\mathrm{C} 18$ as a sorbent in combination with cyclohexane/acetone solvent mixture because of the highest mean recovery values obtained due to excellent results for pyrene (111.99\%) and fluoranthene $(80.22 \%)$, so this combination is suitable for the two compounds analysis. PSA as a sorbent gave satisfactory results in combination with hexane/acetone and acetonitrile/methanol for benzo[g,h,i]perylene (90.17\% and $103.86 \%$, respectively), and could be also used in benzo[g,h,i]perylene analysis.

\section{Acknowledgment}

The research was supported by the Ministry of Education, Science and Technological Development of the Republic of Serbia (OI 172047).

\section{References}

[1] K. C. Jones, R. E. Alcock, D. L. Johnson, K. T. Semple, P. J. Woolgar, Organic chemicals in contaminated land : analysis, significance and research priorities, Land Contamination and Reclamation, 4(3) (1996) 189-198.

[2] International Agency for Research on Cancer (IARC), IARC monographs on the evaluation of carcinogenic risks to humans, (2009) Vols 1-97 IARC publications, Lyon.

[3] European Commission (EC), Commission recommendation of 4 February 2005 on the further investigation into the levels of polycyclic aromatic hydrocarbons in certain foods, (2005) Official Journal of the European Union, L 34, 43-45.

[4] A. R. Johnsen, L. Y. Wick, H. Harms, Principles of microbial $\mathrm{PAH}-$ degradation in soil, Environmental Pollution, 133(1) (2005) 71-84.

[5] Agency for Toxic Substances and Disease Registry (ATSDR), Public Health Statement for Polycyclic Aromatic Hydrocarbons (PAHs) (2006).

[6] S. D. Dubowsky, L. A. Wallace, T. J. Buckley, The contribution of traffic to indoor concentrations of polycyclic aromatic hydrocarbons, Journal of Exposure Analysis and Environmental Epidemiology, 9 (1999) 312-321.

[7] O. Endo, M. Koyano, S. Mineki, S. Goto, K. Tanabe, H. Yajima, T. Ishii, H. Matsushita, Estimation of Indoor Air $\mathrm{PAH}$ Concentration Increases by Cigarette, IncenseStick, and Mosquito-Repellent-Incense Smoke, Polycyclic Aromatic Compounds, 21 (1-4) 2000 261-272.

[8] J. M. Neff, Polycyclic Aromatic Hydrocarbons in the aquatic environment, Applied Science Publishers LTD, London, 1979, p. 262.

[9] B. K. Larsson, G. P. Sahlberg, A. T. Eriksson, L. A. Busk, Polycyclic aromatic hydrocarbons in grilled food, Journal of Agriculture and Food Chemistry, 31 (1983) 867-873.

[10] B. Tang, U. Isacsson, Analysis of mono- and polycyclic aromatic hydrocarbons using solid-phase micro extraction: State-of-the-Art, Energy Fuels, 22 (2008) 1425 -1438.
[11] M. Rawa-Adkonis, L. Wolska, J. NamieĞnik, J. Analytical Procedures for PAH and PCB Determination in Water Samples-Error Sources, Critical Reviews in Analytical Chemistry, 36(2) (2006) 63-72.

[12] M. Anastassiades, S. J. Lehotay, D. Stajnbaher, F. J. Schenck, Fast and easy multiresidue method employing acetonitrile extraction/partitioning and "dispersive solidphase extraction" for the determination of pesticide residues in produce, Journal of AOAC International, 86 (2003) 412-431.

[13] COMMISSION REGULATION (EU) No 836/2011 of 19 August 2011 Official Journal of the European Union

[14] J. D. Berset, M. Ejem, R. Holzer, P. Lischer, Comparison of different drying, extraction and detection techniques for the determination of priority polycyclic aromatic hydrocarbons in background contaminated soil samples, Analytica Chimica Acta, 383 (3) (1999) 263-275.

[15] A. Sadowska-Rociek, M. Surma, E. Cieślik, Comparison of different modifications on QuEChERS sample preparation method for PAHs determination in black, green, red and white tea, Environmental Science and Pollution Research, 21(2) (2013) 1326-38.

[16] E. W. Abel, F.H. Pollard, P.C. Uden, G. Nickless, A new gas-liquid chromatographic phase, Journal of Chromatography A, 22 (1966) 23-28.

[17] R. A. Kanaly, S. Harayama. Biodegradation of highmolecular-weight polycyclic aromatic hydrocarbons by bacteria, Journal of Bacteriology, 182 (2000) 2059-2067.

[18] M. Surma , A. Sadowska Rociek , E. Cieslik, The application of d SPE in the QuEChERS method for the determination of PAHs in food of animal origin with GCMS detection, European Food Research and Technology, 238 (2014) 1029-1036

[19] N. Masqué, R. M. Marce, F. Borrull, New polymeric and other types of sorbents for solid-phase extraction of polar organic micropollutants from environmental water, Trends in Analytical Chemistry, 17 (1998) 384-389.

[20] N. Masqué, M. Galià, R. M. Marcé, F. Borrull, (1998). New chemically modified polymeric resin for solid-phase extraction of pesticides and phenolic compounds from water, Journal of Chromatography A, 803 (1998) 147-155.

[21] M.R. Burkhardt, S.D. Zaugg, T.L. Burbank, M.C. Olson, J.L. Iverson, Pressurized liquid extraction using water/ isopropanol coupled with solid-phase extraction cleanup for semivolatile organic compounds, polycyclic aromatic hydrocarbons (PAH), and alkylated $\mathrm{PAH}$ homolog groups in sediment, Analytica Chimica Acta, 549 (2005) 104-116. 


\section{Izvod \\ ISPITIVANJE MOGUĆNOSTI PRIMENE RAZLIČITIH ADSORBENASA I SMEŠA RASTVARAČA U PRIPREMI UZORAKA ZA GC/GC-MS ANALIZU POLICIKLIČNIH AROMATIČNIH UGLJOVODONIKA}

Jelena S. Cvetković, Violeta D. Mitić, Vesna P. Stankov Jovanović, Marija V. Dimitrijević, Gordana S. Stojanović

Univerzitet u Nišu, Prirodno-matematički fakultet, Departman za hemiju, Niš, Srbija

Analiza policikličnih aromatičnih ugljovodonika (PAU) u složenim uzorcima zahteva prethodnu pripremu uzoraka. $U$ ovom radu opisana je metoda ekstrakcije dispergovanom čvrstom fazom, kao koraka u pripremi uzoraka. Korišćene su tri smeše rastvarača i tri različita adsorbensa (PSA, C18 i PS-DVB) u cilju određivanja uticaja smeše rastvarača/adsorbensa na tačnost celokupne analize. Recovery-vrednosti varirale su u zavisnosti od adsorbensa i analiziranih jedinjenja. Najveća srednja recovery-vrednost zabeležena je za smešu cikloheksan/aceton - C18 (58.45\%), sa najvećim pojedinačnim vrednostima za naftalen (76.05\%), fluoranten (80.22\%) i benzo[g,h,i]perilen (71.77\%). Slične srednje recovery-vrednosti zabeležene su za kombinacije cikloheksan/aceton-PS-DVB $(55.50 \%)$ i cikloheksan/aceton-PSA $(55.30 \%)$. Smeša cikloheksana i acetona dala je najviše vrednosti sa sva tri korišćena adsorbensa, pa može biti korišćena u ekstrakciji PAU. lako recoveryvrednosti nisu na visokom nivou, mogu poslužiti kao osnova za dalja istraživanja, $\mathrm{s}$ obzirom na to da PS-DVB, prema saznanjima autora, nije ranije korišćen $u$ pripremi uzoraka za analizu PAU-a.
(ORIGINALNI NAUČNI RAD) UDK 543.51:547.6:66.061.3

Ključne reči: PAU, GC/GC-MS, priprema uzoraka, dSPE, adsorbens 